\title{
HUBUNGAN KUNJUNGAN ANTENATAL CARE DAN BERAT BADAN LAHIR RENDAH TERHADAP KEJADIAN STUNTING DI KOTA BATU
}

\author{
Anindya Hapsari1*, Yuyun Fadhilah, Hartati Eko Wardani \\ Program Studi S1 Ilmu Kesehatan Masyarakat, Fakultas Ilmu Keolahragaan, Universitas Negeri Malang, \\ Malang, Indonesia \\ email: anindya.hapsari.fik@um.ac.id
}

\begin{abstract}
Abstrak
Stunting merupakan salah satu permasalahan gizi kronis yang menyebabkan gangguan pada masa window of opportunity anak. Stunting diketahui dapat disebabkan oleh banyak faktor, antara lain kunjungan Antenatal Care (ANC) dan Berat Badan Lahir Bayi Rendah. Penelitian ini bertujuan untuk mengetahui hubungan antara kunjungan ANC dan berat badan lahir bayi terhadap kejadian stunting di Kota Batu. Penelitian ini merupakan penelitian analitik observasional dengan desain cross sectional. Populasi dalam penelitian ini adalah ibu yang mempunyai bayi usia 0-12 bulan di wilayah Kelurahan Temas Kota Batu. Pengambilan sampel dengan menggunakan teknik purposive sampling, dimana didapat sampel sebanyak 70 responden. Teknik analisis data menggunakan uji korelasi Spearman. Hasil penelitian ini menyatakan bahwa terdapat hubungan yang signifikan antara kunjungan ANC terhadap kejadian stunting $(p=0,000)$, dan tidak terdapat hubungan yang signifikan antara berat badan lahir bayi terhadap kejadian stunting di Kota Batu $(p=0,140)$. Kesimpulan yang didapatkan adalah bahwa kunjungan ANC saat hamil memiliki hubungan terhadap kejadian stunting di wilayah Kota Batu. Sedangkan berat badan lahir bayi tidak memiliki hubungan yang signifikan terhadap kejadian stunting di Kota Batu.
\end{abstract}

Kata kunci: Antenatal Care, ASI esklusif, stunting

\begin{abstract}
Stunting is one of chronic nutritional problems that made a disruption on children's window of opportunity period. Stunting can be caused by multifactor, including antenatal care (ANC) visit and low birth weight. This study aimed to determine the correlation between ANC visit and low birth weight with the incidence of stunting in Batu City. This study used an observational analytic study design with a cross sectional approach. The population in this study were mothers who had babies aged 0-12 months in the Temas Village, Batu City. Sampling used purposive sampling technique, which obtained respondents as many as 70 respondents. The data analysis technique used Spearman test. The results of this study indicated that there was a significant correlation between ANC visits with the incidence of stunting $(p=0.000)$. And there was no significant correlation between low birth weight with the incidence of stunting in Batu City $(p=0,140)$. This study concluded that ANC visits during pregnancy had a correlation with the incidence of stunting in Batu City. Meanwhile, low birth weight had no correlation with the incidence of stunting in Batu City.
\end{abstract}

Keywords: Antenatal Care, exclusive breastfeeding, stunting.

\section{PENDAHULUAN}

Seribu hari pertama kehidupan atau sering disebut sebagai window of opportunity, merupakan masa yang sangat penting dalam perkembangan seseorang. Masa ini dimulai sejak masa gestasi hingga usia 2 tahun. Pada masa ini, terjadi pertumbuhan dan perkembangan yang pesat, baik dari dari sel-sel saraf di otak, tulang, otot, dan berbagai sistem organ yang lain (Martorell, 2017).

Gangguan nutrisi ketika masa window of oppurtunity, dapat berakibat jangka panjang. Akibat ini dapat dimulai sejak masa kanak-kanak maupun ketika dewasa, yaitu berupa peningkatan risiko kesehatan, seperti: obesitas, penyakit kardiovaskuler, penyakit metabolik dan juga gangguan endokrin. Selain itu, kegagalan memenuhi jumlah 
energi dan nutrisi yang tepat pada masa ini dapat berakibat pada terjadinya stunting dan defisit jangka panjang pada fungsi otak (Scott, 2020).

Stunting adalah kondisi kegagalan dalam pertumbuhan yang diakibatkan oleh kegagalan mendapatkan kenaikan berat badan, gangguan pada pertumbuhan linear dan lingkar kepala, serta malnutrisi yang berakibat anak memiliki tinggi badan tidak sebanding dengan teman usianya (Tim Nasional Percepatan Penanggulangan Kemiskinan, 2017). Stunting didefinisikan sebagai tinggi badan yang rendah pada $z$ score. Keadaan ini dimulai sejak masa prenatal yang mengakibatkan terjadinya berat badan lahir rendah dan terus mempengaruhi pertumbuhan terutama pada 2 tahun pertama kehidupan (Roediger, 2020). Stunting menjadi perhatian internasional dan ditetapkan sebagai masalah kesehatan masyarakat utama. Hal ini antara lain dikarenakan stunting memiliki dampak terhadap kesehatan jangka pendek dan jangka panjang, serta mempengaruhi fungsional individu termasuk rendahnya fungsi kognitif dan produktivitas di masa depannya. Selain itu, stunting terjadi pada masa window of oppurtunity, dimana pertumbuhan linier pada masa ini sangat sensitif terhadap faktor lingkungan antara lain nutrisi, infeksi, dan psikososial. Dengan demikian, pengubahan pada faktor lingkungan dapat mereduksi stunting. Modifikasi lingkungan ini memerlukan respon multisektor karena untuk mereduksi stunting diperlukan berbagai hal, meliputi: pengembangan ketahanan makanan dan nutrisi; edukasi; intervensi air, higiene, dan sanitasi; kesehatan; pemberantasan kemiskinan; dan pemberdayaan wanita (de Onis, 2016).

Prevalensi stunting di dunia masih cukup besar dimana sebesar 150,8 juta $(22,2 \%)$ balita mengalami stunting dan Indonesia termasuk lima besar negara di dunia dengan angka stunting yang tinggi (Kemkes, 2018). Indonesia memiliki prevalensi jumlah balita stunting mencapai (37\%) atau sebanyak kurang lebih 9 juta anak balita (Kemkes, 2018). Dalam Data Kantor Staf Presiden (KSP) menyebutkan bahwa sebanyak 48,4\% stunting terjadi pada balita di keluarga yang masuk dalam $20 \%$ masyarakat termiskin, dan $29 \%$ masyarakat terkaya. Stunting tak hanya terjadi di pedesaan saja $(42,1 \%)$, akan tetapi juga banyak terjadi di kawasan perkotaan $(32,5 \%)$ (Kementerian Kesehatan Republik Indonesia, 2018). Berdasarkan data Riset Kesehatan Dasar tahun 2018, angka prevalensi stunting di Jawa Timur sebesar 33\% (Kesehatan, Penelitian and Kesehatan, 2018). Berdasarkan data Profil Kesehatan Kota Batu di tahun 2014, sebanyak 66 balita $(0,6 \%)$ merupakan jumlah balita di Bawah Garis Merah (BGM) dari keseluruhan anak yang sudah tertimbang. Angka tersebut masih terbilang tinggi karena pencapaian Bawah Garis Merah/Daerah (BGM/D) di Kota Batu masih berada di bawah standar Nasional (Dinkes Kota Batu, 2014). Salah satu kelurahan di Kota Batu adalah Kelurahan Temas yang diketahui memiliki jumlah balita stunting mencapai 138 dengan rincian 101 balita pendek dan 37 balita sangat pendek per-bulan Agustus 2019.

Berbagai hal diketahui dapat mempengaruhi kejadian stunting. Menurut (Andiani, 2013), menyebutkan bahwa stunting dapat disebabkan oleh banyak faktor. Faktor lingkungan yang mempengaruhi stunting dapat dibedakan menjadi faktor langsung dan faktor tidak langsung. Contoh dari faktor langsung antara lain jenis kelamin, berat badan lahir rendah $(<2500$ gram $)$, panjang badan lahir rendah $(<48 \mathrm{~cm})$, asupan gizi, dan penyakit infeksi (de Onis, 2016; Rukmana, 2016). Sedangkan faktor yang mempengaruhi stunting secara tidak langsung antara lain: faktor sosial ekonomi seperti pendidikan orang tua, pekerjaan orang tua, pendapatan orang tua; kunjungan pelayanan Antenatal Care (ANC) ibu saat hamil ke fasilitas pelayanan kesehatan, pola asuh dalam pemberian Air Susu Ibu (ASI) eksklusif, dan sanitasi lingkungan (Amini, 2016; Rukmana, 2016).

Salah satu faktor resiko yang mempengaruhi kejadian stunting adalah Antenatal Care. Antenatal Care (ANC) merupakan asuhan antenatal yang berupa pelayanan kesehatan untuk ibu hamil yang 
diberikan oleh tenaga kesehatan profesional (dokter spesialis kandungan dan kebidanan, dokter umum, bidan, dan perawat) selama kehamilan dan dilaksanakan sesuai dengan standar pelayanan yang ditetapkan guna mendeteksi risiko terjadinya komplikasi kehamilan serta mempengaruhi persepsi dan keputusan selama proses kehamilan sampai masa nifas. Antenatal Care (ANC) merupakan salah satu pilar dari safe motherhood (Mulyanto, 2015). Berdasarkan penelitian terdahulu yang dilakukan Amini (2016) mengatakan bahwa faktor dominan yang mempengaruhi kejadian stunting balita di kabupaten $\mathrm{X}$ adalah kunjungan ANC, disebutkan juga ibu yang melakukan kunjungan ANC tidak terstandar memiliki resiko 2,28 kali memiliki balita stunting dibandingkan dengan ibu dengan kunjungan ANC terstandar (Amini, 2016). Standar ANC yang sudah ditetapkan oleh pemerintah adalah melakukan kunjungan ANC minimal empat kali selama kehamilan, dengan tujuan untuk menjaga ibu sehat selama kehamilan, persalinan, dan nifas serta mengusahakan bayi yang dilahirkan sehat (Susilowati, 2017).

Faktor lain yang mempengaruhi kejadian stunting dibuktikan oleh penelitian yang dilakukan Fitri (2018) menyebutkan bahwa ada hubungan yang bermakna antara berat badan lahir rendah (BBLR) dengan kejadian stunting dengan nilai p-value 0,000 $<0,05$ (Fitri, 2018). Berat badan lahir rendah diartikan sebagai bayi yang lahir dengan berat badan kurang dari 2.500 gram (Mahayana, 2015). Status gizi ibu saat hamil merupakan faktor yang dapat menyebabkan bayi lahir dengan BBLR. Ibu yang kekurangan gizi pada saat kehamilan memiliki kemungkinan besar untuk melahirkan bayi dengan BBLR (Fitri, 2018).

Tujuan penelitian ini adalah untuk mengetahui hubungan kunjungan Antenatal Care (ANC) dan berat badan lahir rendah terhadap kejadian stunting di Kota Batu.

\section{METODE PENELITIAN}

Penelitian ini merupakan penelitian analitik observasional dengan desain cross sectional. Data yang digunakan adalah data sekunder dari buku KIA ibu. Penelitian ini telah memperoleh sertifikat laik etik dengan nomor E.5.a/049/KEPK-UMM/VIII/2020. Dalam penelitian ini, variabel independen adalah kunjungan Antenatal Care dan berat badan lahir bayi. Sedangkan variabel dependen adalah kejadian stunting. Penelitian ini dilaksanakan di Kelurahan Temas Kota Batu pada Bulan September 2020 hingga Oktober 2020.

Populasi dalam penelitian ini adalah seluruh ibu yang memiliki bayi berusia 0-12 bulan di Kelurahan Temas Kota Batu. Sampel dalam penelitian ini sebanyak 70 responden yang diambil menggunakan purposive sampling dengan menggunakan kriteria inklusi, yaitu: 1) Ibu yang berdomisili di Kelurahan Temas Kota Batu, 2) Ibu yang mempunyai bayi usia 0-12 bulan pada saat penelitian, 3) Ibu yang mempunyai buku KIA, 4) Bersedia menjadi responden yang dibuktikan dengan bersedia mentandatangani lembar persetujuan menjadi responden (informed consent).

Analisis data dalam penelitian ini adalah univariat dan bivariat. Analisis univariat digunakan untuk mendeskripsikan karakteristik variabel, sedangkan analisis bivariat digunakan untuk menjabarkan hasil variabel bebas dan variabel terikat dengan menggunakan uji Spearman.

\section{HASIL DAN PEMBAHASAN}

Hasil analisis data ditampilkan dalam bentuk tabel sebagai berikut:

Tabel 1. Karakteristik Responden

\begin{tabular}{lcc}
\hline \multicolumn{1}{c}{ Variabel } & Jumlah & $\begin{array}{c}\text { Persentase } \\
(\mathbf{\%})\end{array}$ \\
\hline $\begin{array}{l}\text { Berat Badan } \\
\text { Lahir }\end{array}$ & & \\
$\quad<2.500$ gram & 1 & 1,4 \\
$\quad \geq 2.500$ gram & 69 & 98,6 \\
Kunjungan ANC & & \\
$\quad$ Tidak standar & 38 & 54,3 \\
$\quad$ Standar & 32 & 45,7 \\
Kejadian & & \\
Stunting & & \\
$\quad$ Stunting & 32 & 45,7 \\
$\quad$ Normal & 38 & 54,3 \\
\hline Total & 70 & 100 \\
\hline
\end{tabular}


Karakteristik responden pada penelitian ini terdiri dari berat badan lahir, kunjungan Antenatal Care, dan kejadian stunting pada balita, yang ditampilkan pada tabel 1 . Berdasarkan tabel 1 dapat dilihat bahwa sebagian besar responden yang terlibat dalam penelitian ini memiliki berat badan lahir normal, yaitu lebih dari 2.500 gram.

Sedangkan, karakteristik responden berdasarkan kunjungan Antenatal Care memperlihatkan bahwa sebagian besar responden melakukan kunjungan Antenatal Care tidak standar atau kurang dari 4 kali selama kehamilannya. Karakteristik responden yang lain yang diteliti dalam penelitian ini adalah kejadian stunting pada balita dimana diketahui bahwa hanya $45,7 \%$ dari responden yang terkategori stunting berdasarkan $z$-score. Sedangkan sebagian besar responden tidak mengalami stunting.

Tabel 2. Hubungan Kunjungan ANC terhadap Stunting di Kota Batu

\begin{tabular}{ccccc}
\hline Frekuensi & \multicolumn{2}{c}{ Kategori } & Total & $\boldsymbol{P}$ \\
\cline { 2 - 4 } Kunjungan ANC & Stunting & Normal & $38(100 \%)$ & 0,000 \\
\hline Tidak Standar & $30(78,95 \%)$ & $8(21,05 \%)$ & $32(100 \%)$ & \\
Standar & $2(6,25 \%)$ & $30(93,75 \%)$ & 70 & \\
\hline Total & 32 & 38 & \\
\hline
\end{tabular}

Tabel 2 menunjukkan adanya hubungan antara frekuensi kunjungan Antenatal Care dengan kejadian stunting. Bayi yang terlahir dari ibu yang tidak melakukan kunjungan Antenatal Care sesuai standar sebesar 78,95\% mengalami stunting. Hasil uji Spearman diperoleh nilai $p$-value $0,000(\mathrm{p}<0,05)$ sehingga dapat disimpulkan bahwa terdapat hubungan yang signifikan antara riwayat kunjungan ANC terhadap stunting di Kota Batu.

Hasil penelitian ini serupa dengan penelitian yang dilakukan oleh Hutosit, dkk (2019), yang menyebutkan bahwa ada hubungan yang signifikan antara kunjungan ANC terhadap kejadian stunting. Hasil analisis penelitian ini memperoleh nilai $p$ value sebesar 0,000 (Hutasoit, 2020).

Ibu hamil yang tidak melaksanakan pelayanan ANC berisiko 3,4 kali terjadinya stunting. Kunjungan ANC sangat penting untuk ibu hamil, selain supaya ibu mampu mempersiapkan kelahirannya, ANC juga bertujuan untuk memantau kesehatan ibu dan bayi selama kehamilan dan mencegah adanya risiko kehamilan dan komplikasi bagi ibu dan janin (Budiastutik, 2019).

Standar kunjungan ANC selama kehamilan yaitu: satu kali kunjungan pada trimester pertama (K1), satu kali kunjungan pada trimester kedua (K2), dan dua kali pada trimester ketiga (K3) dan (K4)
(Camelia, 2020). Frekuensi ANC sesuai standar selama kehamilan bertujuan untuk menelusuri hal-hal yang sekecil kecilnya mengenai segala sesuatu yang mungkin dapat mempengaruhi kesehatan ibu dan bayinya. Sehingga apabila ditemukan gangguan pada kehamilan, segera dilakukan upaya koreksi sesuai dengan pedoman pelayanan antenatal yang ditentukan (Malka, Musni and Fatimah, 2021).

Standar pelayanan Antenatal Care meliputi "11T", yaitu penimbangan berat badan, pengukuran lingkar lengan atas (LILA), pengukuran tekanan darah, pengukuran tinggi fundus uteri, penghitungan denyut jantung janin (DJJ), penentuan presentasi janin, pemberian imunisasi Tetanus Toxoid (TT), pemberian tablet tambah darah (tablet besi), pemeriksaan laboratorium (rutin dan khusus), penatalaksanaan penanganan kasus dan Komunikasi Informasi Edukasi (KIE) efektif (Camelia, 2020). Pemeriksaan LILA dilakukan sejak K1 pada ibu hamil dengan tujuan mengetahui ibu hamil masuk dalam kategori ibu kurang energi kronis (KEK) atau tidak. Tindakan ini penting dilakukan karena bukan hanya untuk menepis ibu hamil yang KEK, tetapi juga untuk mengetahui kemungkinan resiko melahirkan stunting (Ruaida, 2018). 
Penelitian lain pada tiga negara Amerika Latin oleh Ramirez, dkk (2012), menjelaskan bahwa kunjungan ANC menjadi salah satu faktor risiko terjadinya stunting. Kunjungan ANC memiliki pengaruh yang signifikan secara stastistik dan besar pada penurunan gizi buruk di Kolumbia dan Peru. Namun, di Bolivia tidak ada pengaruh secara signifikan antara riwayat kunjungan ANC dengan stunting ( $p$-value 0,437). Variasi antar negara tersebut berbeda disebabkan oleh perbedaan dari kualitas ANC. Penambahan kualitas ANC di Kolumbia, seperti memberikan suplemen vitamin dan tindakan pelengkap lainnya menjadi penyebab layanan ANC menjadi berkualitas dibandingan di Bolivia (Ramirez, 2012).

Hasil penelitian ini sesuai dengan teori bahwa riwayat kunjungan Antenatal Care merupakan salah satu faktor risiko kejadian stunting. Hal ini dikarenakan apabila kunjungan ANC dilakukan rutin dapat mendeteksi dini risiko kehamilan yang ada pada ibu, terutama yang berkaitan dengan masalah gizi dan nutrisinya (Najahah, Adhi and Pinatih, 2013). World Health Organization menyebutkan bahwa stunting dapat berawal dari kondisi gizi ibu hamil, bahkan sebelum hamil, dimana hal ini akan menentukan pertumbuhan janin (Rahmaningtyas, 2020). Proses terjadinya stunting dilalui dengan proses yang panjang, diawali dengan gagal tumbuh, baik yang terjadi selama kehamilan maupun dua sampai tiga tahun pertama kehidupan. Pada saat hamil, janin akan mengalami pertumbuhan dan perkembangan yang sangat cepat sehingga kualitas makanan ibu, kesehatan, serta gaya hidup ibu dapat mempengaruhi janin yang dikandungnya (Heryanto, 2021). Oleh karena itu, kunjungan ANC sesuai standar baik secara kuantitas dan kualitas, sangat penting untuk mendeteksi status gizi ibu dan akhirnya mencegah terjadinya stunting.

Tabel 3. Hubungan Berat Badan Lahir terhadap Kejadian Stunting di Kota Batu

\begin{tabular}{|c|c|c|c|c|}
\hline \multirow{2}{*}{$\begin{array}{c}\text { Berat Badan } \\
\text { Lahir Bayi }\end{array}$} & \multicolumn{2}{|c|}{ Kategori } & \multirow[b]{2}{*}{ Total } & \multirow[b]{2}{*}{$P$} \\
\hline & Stunting & Normal & & \\
\hline BBLR & $\begin{array}{c}1 \\
(100 \%)\end{array}$ & $\begin{array}{c}0 \\
(0 \%)\end{array}$ & $\begin{array}{c}1 \\
(100 \%)\end{array}$ & 0,140 \\
\hline Tidak BBLR & $\begin{array}{c}31 \\
(44,93 \%)\end{array}$ & $\begin{array}{c}38 \\
(55,07 \%)\end{array}$ & $\begin{array}{c}69 \\
(100 \%)\end{array}$ & \\
\hline Total & 32 & 38 & 70 & \\
\hline
\end{tabular}

Berdasarkan tabel 3 menunjukkan tidak adanya hubungan antara berat badan lahir dengan kejadian stunting. Pada penelitian ini, diketahui bahwa hanya 1 responden yang mengalami stunting terlahir dengan berat badan lahir rendah. Sedangkan, sebanyak 31 orang responden stunting terlahir dengan berat badan normal. Hasil uji Spearman diperoleh nilai $p$-value $0,140(\mathrm{p}>0,05)$ sehingga dapat disimpulkan bahwa tidak terdapat hubungan yang signifikan antara berat badan lahir bayi terhadap kejadian stunting di Kota Batu.

Hasil penelitian ini bertentangan dengan penelitian yang dilakukan oleh Rahayu dkk (2015) yang menyatakan bahwa anak dengan riwayat BBLR akan lebih besar berisiko mengalami stunting dibandingkan dengan yang tidak BBLR $(\mathrm{OR}=0,155)$ (Rahayu et al., 2015). Hasil penelitian ini juga tidak sesuai dengan penelitian Aryastami dkk (2017) yang mendapatkan hasil bahwa bayi BBLR 1,74 kali lebih beresiko mengalami stunting (Aryastami et al., 2017).

Penelitian ini menunjukkan bahwa kejadian stunting di Kota Batu tidak dipengaruhi oleh berat badan lahir bayi. Hal ini sesuai dengan teori bahwa kejadian stunting disebabkan multifactor. Stunting dapat disebabkan faktor langsung dan tidak langsung. Faktor langsung yang mempengaruhi kejadian stunting, antara lain: jenis kelamin, panjang badan lahir rendah $(<48 \mathrm{~cm})$, asupan gizi, dan penyakit 
infeksi (de Onis, 2016; Rukmana, 2016). Kejadian stunting juga dapat dipengaruhi oleh faktor tidak langsung seperti: pendidikan orang tua, pekerjaan orang tua, pendapatan orang tua, pola asuh dalam pemberian Air Susu Ibu (ASI) eksklusif, dan sanitasi lingkungan (Amini, 2016; Rukmana, 2016).

\section{KESIMPULAN DAN SARAN}

Kesimpulan dari penelitian ini adalah: terdapat hubungan yang signifikan antara kunjungan ANC terhadap kejadian stunting di Kota Batu dan tidak terdapat hubungan yang signifikan antara berat badan lahir terhadap kejadian stunting di Kota Batu

Saran bagi peneliti selanjutnya adalah perlunya penelitian lanjutan terhadap faktor lain yang memungkinkan terhadap kejadian stunting, antara lain: jenis kelamin bayi, panjang badan lahir rendah $(<48 \mathrm{~cm})$, asupan gizi, penyakit infeksi, faktor sosial ekonomi, pola asuh dalam pemberian Air Susu Ibu (ASI) eksklusif, dan sanitasi lingkungan. Selain itu, kualitas Antenatal Care yang disediakan tenaga kesehatan juga dapat dijadikan bahan kajian tersendiri mengingat kualitas sama pentingnya dengan kuantitas dalam mencegah kejadian stunting pada bayi.

Sedangkan, saran bagi pemangku kebijakan adalah perlunya diadakan program intervensi dengan fokus kesehatan ibu dan anak untuk mengurangi risiko semakin banyaknya anak yang mengalami stunting.

\section{REFERENSI}

Amini, A. (2016) 'Hubungan Kunjungan Antenatal Care (ANC) dengan Kejadian Stunting pada Balita Usia 12-59 Bulan di Kabupaten Lombok Utara Provinsi NTB Tahun 2016', pp. 2-22.

Aryastami, N. K. et al. (2017) 'Low birth weight was the most dominant predictor associated with stunting among children aged 12-23 months in Indonesia', BMC Nutrition. BMC Nutrition, 3(1), pp. 16. doi: 10.1186/s40795-017-0130-x.

Budiastutik, I. and Rahfiludin, M. Z. (2019) 'Faktor Risiko Stunting pada anak di Negara Berkembang', Amerta Nutrition, 3(3), pp. 122-129. doi: 10.2473/amnt.v3i3.2019.122-129.
Camelia, V. (2020) 'Hubungan Antara Kualitas \& Kuantitas Riwayat Kunjungan Antenatal Care (ANC) Dengan Stunting Pada Balita Usia 2459 Bulan Di Kecamatan Pujon Kabupaten Malang,, Journal of Issues in Midwifery, 4(3), pp. 100-111. doi: 10.21776/ub.joim.2020.004.03.1.

Dinkes Kota Semarang (2013) 'Profil Kesehatan Kota Batu Tahun 2013', Dinas Kesehatan Kota batu, pp. 1-207.

Fitri, L. (2018) 'Hubungan Bblr Dan Asi Ekslusif Dengan Kejadian Stunting Di Puskesmas Lima Puluh Pekanbaru', Jurnal Endurance, 3(1), p. 131. doi: 10.22216/jen.v3i1.1767.

Heryanto, M. L. (2021) 'Kunjungan Antenatal Care Dengan Kejadian Stunting Pada Anak Usia 24 - 36 Bulan', Jurnal Ilmiah PANNMED (Pharmacist, Analyst, Nurse, Nutrition, Midwivery, Environment, Dentist), 16(1), pp. 1-8. doi: 10.36911/pannmed.v16i1.1043.

Hutasoit, M., Utami, K. D. and Afriyliani, N. F. (2020) 'Kunjungan Antenatal Care Berhubungan Dengan Kejadian Stunting', Kesehatan Samodra Ilmu, 11(1), pp. 1-10.

Kementerian kesehatan Repubelik Indonesia (2018) 'Data dan Informasi profil Kesehatan Indonesia 2018'.

Kemkes (2018) 'Penanganan Stunting Terintegrasi Beban Ganda Permasalahan Gizi di Indonesia', Jakarta.

Kesehatan, K., Penelitian, B. and Kesehatan, P. (2018) 'Hasil Utama Riskesdas 2018'.

Mahayana, S. A. S., Chundrayetti, E. and Yulistini, Y. (2015) 'Faktor Risiko yang Berpengaruh terhadap Kejadian Berat Badan Lahir Rendah di RSUP Dr. M. Djamil Padang', Jurnal Kesehatan Andalas, 4(3), pp. 664-673. doi: 10.25077/jka.v4i3.345.

Malka, S., Musni, M. and Fatimah, S. (2021) 'Faktorkehamilan Dini, Antenatal Care, Asi Eksklusif Dan Pengetahuan Gizi Terhadap Stunting Pada Balita Resiko Stunting Pada Balita Di Kabupaten Bone', Jurnal Kebidanan Malahayati, 7(1), pp. 59-64. doi: 10.33024/jkm.v7i1.3364. 
Martorell, R. (2017) 'Improved nutrition in the first 1000 days and adult human capital and health', American Journal of Human Biology, 29(2), pp. 1-24. doi: 10.1002/ajhb.22952.

Mulyanto, A. D. (2015) 'Faktor-Faktor yang Berhubungan dengan Perilaku Ibu Hamil dalam Melakukan Kunjungan Antenatal Care (Studi Kasus di Wilayah Kerja Puskemas Bawen)', pp. 71-99.

Najahah, I., Adhi, K. T. and Pinatih, G. I. (2013) 'Laporan hasil penelitian Faktor risiko balita stunting usia 12-36 bulan di Puskesmas Dasan Agung, Mataram , Provinsi Nusa Tenggara Barat Risk factors stunting for 12-36 month old children in Dasan Agung Community Health Centre , Mataram , West Nusa Tengg,, Public Health and Preventive Medicine Archive, 1(2), pp. 134-141.

de Onis, M. and Branca, F. (2016) 'Childhood stunting: A global perspective', Maternal and Child Nutrition, 12, pp. 12-26. doi: 10.1111/mon.12231.

Rahayu, A. et al. (2015) 'penyebab stunting baduta 882-1912-1-PB', Jurnal Kesehatan Masyarakat Nasional, 10(2), pp. 67-73.

Rahmaningtyas, I. I. (2020) 'Penanganan Balita Stunting Pada Keluarga di Wilayah Kerja Puskesmas Sukorame Kota Kediri', Jurnal Informasi Kesehatan Indonesia (JIKI), 6(1), pp. 26-38.

Ramirez, N., Gamboa, L. and Bedi, A. (2012) 'Child malnutrition and antenatal care: Evidence from three Latin American countries', ISS Working Paper Series/, (536). Available at: http://repub.eur.nl/pub/31741/.
Roediger, R., Taylor Hendrixson, D. and Manary, M. J. (2020) 'A roadmap to reduce stunting', American Journal of Clinical Nutrition. Oxford University Press, 112, pp. 773S-776S. doi: 10.1093/ajen/nqaa205.

Ruaida, N. and Soumokil, O. (2018) 'Hubungan Status Kek Ibu Hamil Dan Bblr Dengan Kejadian Stunting Pada Balita Di Puskesmas Tawiri Kota Ambon', Jurnal Kesehatan Terpadu (Integrated Health Journal), 9(2), pp. 1-7. doi: 10.32695/jkt.v2i9.12.

Rukmana, E., Briawan, D. and Ekayanti, I. (2016) 'Risk Factors Stunting in Children Aged 6-24 Months in Bogor', Jurnal MKMI2, 12(3), pp. 192-199.

Scott, J. A. (2020) 'The first 1000 days: A critical period of nutritional opportunity and vulnerability', Nutrition and Dietetics, 77(3), pp. 295-297. doi: 10.1111/17470080.12617 .

Sueca, N. P. et al. (2005) 'Faktor - Faktor Determinan', Universitas Stuttgart, $3(2)$.

Susilowati, E. (2017) 'Faktor Risiko Kejadian Stunting Pada Balita 1-5 Th di Puskesmas Bangsri I Faktor Risiko Kejadian Stunting Pada Balita 1-5 Th di Puskesmas Bangsri I', Universitas Muhammadiyah Semarang, 2(1), pp. 7-28.

Tim Nasional Percepatan Penanggulangan Kemiskinan (no date) '100 Kabupaten/Kota Prioritas untuk Intervensi Anak Kerdil (Stunting)', 2. 